\title{
BPK AND BPKP IN DETERMINING STATE FINANCE LOSS IN ORDER TO GAIN ANTI-CORRUPTION LAW EFFICIENCY OF ANTI-CORRUPTION LAW
}

\author{
Gabrielia Febrianty Shofiana \\ Fakultas Hukum Universitas Airlangga Surabaya \\ e-mail: gabrieliafs32@gmail.com
}

\begin{abstract}
Corruption case in Indonesia has been growing rapidly, therefore it needs big efforts to eradicate and prevent corruption, such as establishment of Corruption Eradication Commission (KPK) and the enactment of Law No. 31 Year 1999 as amended by Law No. 20 Year 2001 (Anti-Corruption Law). Corruption itself, as regulated in Article 2 and 3 Anti-Corruption Law, consists of some main elementswhose subject is anyone.The illegal act must exist which aims to enrich themselves and should create loss of state finance or economy. The efficiency of Anti-Corruption Law can be seen by how every article can be fully and properly fulfilled. Only authorized legal entities can determine state finance loss as one of corruption elements. Then, the problems emerge from the legal entity which actually has authority to determine state finance loss, yet if the fulfillment element of state finance loss is not discovered, it means that the corruption suspected cannot be charged. Supreme Audit Board (BPK/SAB) and Finance \& Development Supervisory Board (BPKP/FDSB) are legal entities which have authority to conduct audit investigation. This study, by using normative-empirical research method, will discuss whether both or only one of those state agencies have authority to determine state finance loss.
\end{abstract} Keywords: BPK, corruption law.

\section{INTRODUCTION}

Corruption has been growing rapidly since long time ago, whether the number of the case or how the corrupt people conduct the corrupt action. Indonesia as one of the highest amount of corruption case has been focusing on how and what is the best way to fight against corruption, through any effort in preventing and eradicating the corruption. Therefore, in order to increase the efficiency of preventing and eradicating corruption programme, Indonesia government enacted Anti-Corruption Law ${ }^{1}$ and established Corruption Eradication Commission (or more known as KPK). ${ }^{2}$ The existence of KPK, indeed, has given big impact to the eradicating corruption programme since under its law, it is given some special authorities and duties.

In the Anti-Corruption Law itself, it has already clearly stated some definition of any actions which can be defined as corruption. Anti-Corruption Law, Law No. 31 Year 1999 as amended by Law No. 20

\footnotetext{
${ }^{1}$ Law No. 31 Year 1999 as amended by Law No. 20 Year 2001 concerning Coruption Eradction.

${ }^{2}$ Regulated in Law No. 30 Year 2002 concerning Corruption Eradiction Commission.
}

Year 2001, has regulated corrupt act in some Articles that covers some action such as action which cause state finance loss, bribery, position embezzlement, blackmail, fraud, conflict of interest, gratification, and any other criminal act which related with corruption. Corruption, identically, is related with state finance loss. This research will focus on the action which caused state finance loss as regulated under Article 2 and 3 Anti-Corruption Law.

Article 2 Anti-Corruption Law stated that: First, Anyone who illegally commits an act to enrich oneself or another person or a corporation, thereby creating losses to the state finance or state economy, is sentenced to life imprisonment or minimum imprisonment of 4 (four) years and to a maximum of 20 (twenty) years, and fined to a minimum of Rp 200,000,000,- (two hundred million Rupiahs) and to a maximum of $\mathrm{Rp} 1,000,000,000$,- (one billion Rupiahs). Second, In the event that the criminal act of corruption as referred to in paragraph (1) is committed under certain circumstances, the person concerned can be sentenced to life imprisonment. 
Article 3 stated that, Anyone with the aim of enriching oneself or another person or a corporation, abuses the authority, opportunity or facilities given to him related to his post or position, which creates losses to the state finance or state economy, is sentenced to life imprisonment or minimum sentence of 1 (one) year and maximum sentence of 20 (twenty) years or the minimum fine of $\mathrm{Rp} 50.000 .000$ (fifty Rupiahs) and maximum fine of Rp 1.000.000.000 (one billion rupiahs)

From those article, we can see that there are some elements of how an act can be classified as a corrupt act, those are: The subject is anyone; There must be an illegal act; The act aim is to enrich themselves; Creating loss to the state finance or state economy.

The efficiency of the Anti-Corruption Law implementation can be seen from how actually the elements of every Articles inside the Law can be fulfilled. If we focus on how the fulfilment of creating loss to state finance, we can find a problem which organs actually has authority to determine the state finance loss. It is being very important since state finance loss may give, whether direct or indirect impact, to society.

The existence of Supreme Audit Board (or more known as BPK or SAB) and Finance and Development Supervisory Board (or more known as BPKP or FDSB) gives different opinions among experts and the law enforcer itself, whether both those board or only BPKor SAB has authority to determine state finance loss, which is one of element on corruption act as regulated in Law No. 31 Year 1999 as amended by Law No. 20 year 2001.

This problem cannot be separated from the establishment and status of BPKP/FDSB itself. KPK in its duty and authority as stated in Law No. 30 Year 2002, may cooperate with other organs to eradicate corruption. This research will discuss and analyse which organ actually has authorities to determine state finance loss in regard to the element of corruption as stated in Article 2 and 3 Law No. 31 Year 1999 as amended by Law No. 20 year 2001 concerning Corruption Eradication (Anti-Corruption Law).

How and until what extend the authorities of $\mathrm{BPK} / \mathrm{SAB}$ and BPKP/FDSB, if it is seen from juridical perspective, in determining the state finance loss as one of corruption elements?

\section{METHOD}

legal research is conducted by a method according to the distinctive caracter of legal science. This research used normative type with statute approach wich analysed rule of law.

\section{DISCUSSION}

Before determine state finance loss, it is important to know what actually state finance is and what state finance loss is. According to Geodhart, state finance is the whole law that has been determined periodically which give the government power to implement expenditure in certain period and determine the financial equipment to recover the expenditure. According to Geodhart, elements of state finance are: Periodically; government as the budget executor; budget execution consist of two authorities, which are spending and collecting any financial sources to recover the expenditure; the form of state budget is Law. $^{3}$

According to M. Subagio, state finance consists of rights and obligation of the state which can be calculated with money, and any other things in form of good or money that can be belonged to the state in the implementation of the rights and obligations. The state rights consist of rights to create money, rights to conduct retribution, right to loan, right to produce income, and rights to force. The state obligation consists of obligation to organise the stat duties and obligation to pay the invoice from third party. ${ }^{4}$

State finance as one of important part of Indonesia as state, is regulated in Law no. 17 year 2003 concerning state finance. In that law, it is clearly stated the definition of state finance, which is: ${ }^{5}$

All state rights and obligation that can be calculated with money, and all things whether money or goods which can be belonged to state in the implementation of the rights and obligations.

State finance loss is one of important aspect for governance activity. ${ }^{6}$ State finance loss is needed so that the governance can be held continually in order to

\footnotetext{
${ }^{3}$ W. Riawan Tjandra, Hukum Keuangan Negara, Grasindo, Jakarta, 2006. p. 1.

${ }^{4}$ M. Subagio, Hukum Keuangan Negara R.I., Rajawali Pers, Jakarta, 1988, p. 11.

${ }^{5}$ Law No. 17 Year 2003 concerning state finance.

${ }^{6}$ Berlangsungnya kegiatan penyelenggaraan negara.
} 
gain the state aims. State finance will be the funding source for every governance activities. ${ }^{7}$

State finance loss as one of the elements of corruption has clearly stated in Article 2 and 3 AntiCorruption Law. It means that in the case when the law enforcer, such as KPK, attorney, and police, want to investigate a case and charge the defendant under Anti-Corruption Law, it must fulfil the elements of creating state finance loss. Anti-Corruption Law itself has given such definition regarding the state finance. It can be seen in the general explanation of Law no. 31 year 1999 which defines state finance as: ${ }^{8}$

All state's wealth, in any forms, whether separated or unseparated, including any parts of state's wealth and any rights and obligation arises because of: (a) Under mastery, management, and accountability of state organ officer, whether central or regional; (b) Under mastery, management, and accountability of State Owned Company (BUMN), regional Owned Company (BUMD), foundation, legal entity, and company which invest state capital or invest third party capital based on agreement with state.

\section{Supreme Audit Board (BPK or SAB)}

Basically, from any definitions regarding state finance above, it may be concluded that state finance always relates two main elements, which are any kind of state properties (object) and who manage those properties (subject). Since the state finance gives big impact to the sustainability of the state itself, 1945 Constitution in its amendment regulates about Supreme Audit Board (BPK/SAB) which is given duty in general to keep the stability of state finance by determining and auditing state finance condition.

Chapter VIIIA concerning Supreme Audit Board (BPK/SAB), especially in Article 23E of The 1945

\footnotetext{
${ }^{7}$ Hidayat Pratama Putra, “Tinjauan Hukum Audit Badan Pengawasan Keungan dan Pembangunan terhadap PT Indosat Tbk (Analisis Putusan PTUN Jakarta No. 231/G/2012/PTUNJKT)", Skripsi (Thesis), Fakultas Hukum Universitas Hasanuddin, Makassar, 2014, p. 1-2.

${ }^{8}$ Kekayaan negara yang dimaksud adalah seluruh kekayaan negara, dalam bentuk apapun, yang dipisahkan atau tidak dipisahkan, termasuk di dalamnya segala bagian kekayaan negara dan segala hak dan kewajiban yang timbul karena: (a) Berada dalam penguasaan, pengurusan, dan pertanggungjawaban pejabat lembaga negara, baik di tingkat pusat maupun di daerah. (b) Berada dalam penguasaan, pengurusan, dan pertanggungjawaban Badan Usaha Milik Negara/Badan Usaha Milik Daerah, yayasan, badan hukum, dan perusahaan yang menyertakan modal negara, atau perusahaan yang menyertakan modal pihak ketiga berdasarkan perjanjian dengan negara.
}

Constitution of The Republic of Indonesia, stated that: (1) To determine the management and accountability of the state finance, there shall be a single Supreme Audit Board which shall be free and independent. (2) The result of any examination of state finance shall be submitted to the House of Representative, the Regional Representative Council, and the Regional House of Representative in line with their respective authority. (3) Action following the result of any such examination will be taken by representative institution and/or bodies according to law.

Article 23G stated that: (1) The Supreme Audit Board shall be based in the capital city of the state, and shall have representation in every province; (2) Further provisions concerning the Supreme Audit Board shall be further regulated by law.

It can be clearly seen that 1945 Constitution gives authorities to $\mathrm{BPK} / \mathrm{SAB}$ by attribution. According to Professor Hadjon, attribution authorities are usually given through division of power by constitution. ${ }^{9}$ For responding the attribution from 1945 Constitution, BPK/SAB was established in 1946, and now works in accordance with Law No. 15 Year 2006 concerning BPK/SAB and some other Law such as Law No.17 Year 2003 concerning State finance, Law No. 1 Year 2004 State Treasury, and Law No. 15 Year 2004 concerning Examination of Management and Accountability of State Finance.

In Law No. 15 Year 2006 concerning BPK/SAB, BPK/SAB authorities has clearly stated in Article 9: a. Determine the audit object, plan and conduct the investigation, determine the time and method of the investigation and also compile and present the investigation report; $b$. Ask information and/or document which is obliged to be given by everyone, central government organization unit, Regional Government, other state organs, Bank Indonesia, Stated Owned Company (BUMN), Public Service Organs, Regional Owned Company (BUMD), and other organs or entities which manage state finance; c. Conduct auditing in money and state's properties storage, in place where activities held, state finance administration, and also auditing towards any calculation, documents, evidence, book-keeping, responsibility, and other reports regarding state finance

\footnotetext{
${ }^{9}$ Philipus M. Hadjon, Fungsi Normatif Hukum Administrasi dalam Mewujudkan Pemerintahan yang Bersih, diucapkan pada peresmian penerimaan jabatan Guru Besar dalam Ilmu Hukum pada Fakultas Hukum Universitas Airlangga pada hari Senin, tanggal 10 Oktober 1994
} 
management; d. Determine the types of document, data, and information regarding management and accountability of state finance which must be reported to BPK or SAB; e. Determine state finance investigation standard after conducted consultation with Central or Regional Government which obliged to be used in management and accountability of state finance investigation; $f$. Determine ethics code in management and accountability of state finance investigation; g. Use any experts and or auditor outside BPK or SAB who works for and on behalf of BPK or SAB; $h$. Train the investigator functional position; i. Give any considerations of governmental accounting standard; j. Give any considerations regarding the plan of Central or Regional Government intern preventive system before it is determined by Central or Regional Government.

Article 10 stated that: First, BPK/SAB assess and/ or determine any state finance loss which caused by unlawful act whether intentionally or unintentionally conducted by treasurer, manager of BUMN/BUMD, and any other organs or entities which manage state finance; Second, State finance loss assessment and/ or the determination of which parties are obliged to pay the state finance loss as stated in article (1), is determined by BPK/SAB decision; Third, In order to guarantee the payment of state finance loss, BPK/ SAB has authorities to monitor: a. Completion of state finance loss payment which determines by government over the public officer not treasurer and other public officers; $b$. The execution of state finance loss payment over treasurer, manager of BUMN/ BUMD, and other organs or entities which manage state finance as determined by BPK/SAB; c. The execution of state finance loss payment which is determined by court decision.

Beside this, BPK or SAB duty is also clearly stated in Article 6, which is audit the management and accountability of state finance which conducts by central government organization unit, Regional Government, other state organs, Bank Indonesia, State Owned Company (BUMN), Public Service Organs, Regional Owned Company (BUMD), and other organs or entities which manage state finance. The audit consists of financial audit, performance audit, and audit with certain purposes.

According to BPK/SAB Regulation No. 3 Year 2007 concerning State Finance Loss Compensation Procedure, State finance loss is any kind of deficit in money, marketable securities, and properties, which are factually and clearly determined as the result of unlawful act whether intentionally or unintentionally. State finance loss information can be seen from: a. Investigation of BPK/SAB; b. Supervision of functional supervisory apparatus; c. Supervision and/ or information given by direct boss of treasurer or office/unit chief; d. Ex Officio calculation. ${ }^{10}$

According to Law No. 15 Year 2004 about Examination of Management and Accountability of State Finance, the scope of State Finance examination consists of about examination of state finance management and examination of state finance accountability, and the authorized organs which conducts the examination is BPK/SAB. ${ }^{11}$ Then, in examining state finance management and accountability, BPK/SAB can use the report from intern government supervisory apparatus. ${ }^{12}$

In determining state finance loss, BPK/SAB uses four criteria: 1 . The decreasing of any state wealth and or the increasing of state obligation which deviate from any laws and regulations. While state wealth is the consequences from the receiving profitable income and expenditure as state load (state income minus state outcome). 2. The un-receiving whether half or all profitable state income, which deviate from laws and regulations. 3. Half or all expenditure which become the state finance load (bigger than usual), or it is not supposed to be state finance load, which deviate from laws and regulations. 4. Every accretion in state obligation that caused by deviated commitment which deviate from laws and regulation. ${ }^{13}$

From the Articles above, it can conclude that $\mathrm{BPK} / \mathrm{SAB}$ as an audit organs which is got the authorities attributably from 1945 Constitution, has full authorities and duty whether to audit the

${ }^{10}$ Article 3 BPK Regulation No. 3 Year 2007 concerning State Finance Loss Compentsation Procedure.

Informasi tentang kerugian negara dapat diketahui dari:

a. Pemeriksaan Badan Pemeriksa Keuangan;

b. Pengawas aparat pengawasan fungsional;

c. Pengawasan dan/atau pemberitahuan atasan langsung bendahara atau kepala kantor/satuan kerja;

d. Perhitungan ex officio.

${ }^{11}$ Article 2 and 3 Law No.15 year 2004 concerning Examination of Management and Acoountability of State Finance.

${ }^{12}$ Article 9 Law No. 15 Year 2004 concerning Examination of Management and Acoountability of State Finace.

${ }^{13}$ Adami Chazawi, Hukum Pidana Materiil dan Formil Korupsi di Indonesia, Bayu Media Publidhing, Malang, 2014, p. 58-59. 
management and accountability of state finance and determine the state finance loss. The authority and duty of BPK/SAB cannot be doubted since the Constitution has also been followed by the enactment of Law No. 15 Year 2006 about BPK/SAB.

\section{Finance and Development Supervisory Board (BPKP or FDSB)}

Finance and Development Supervisory Board or known as BPKP/FDSB, firstly works based on President Regulation No. 31 Year 1983. BPKP/FDSB was established in order to maintain independent supervisory organs outside the government unit besides every supervisory body which attached with every government unit. ${ }^{14}$ BPKP/FDSB is a non-Department organs which directly responsible to President. ${ }^{15}$ BKPK in that time, had also authority to conduct any special examinations regarding some cases which had possibility to create loss in Central and Regional Government, and also BUMN and BUMD. ${ }^{16}$ But then President Decision No. 31 Year 1983 is revoked by President Decision No. 42 Year 2001 concerning position, Duties, Functions, Organization Arrangement, and Procedure of Government Organs Non Department. This President Decision also is also revoked by President Regulation No. 103 Year 2001. BPKP/FDSB approach prefer to preventive or coaching and it is not full audit or repressive. Socialization, existence or assistance, and evaluation are the BPKP/FDSB activities. While audit investigative is only conducted in the case of assisting the law enforcer to calculate the state finance loss. ${ }^{17}$

BPKP/FDSB Authority has been being debatable whether it has same authority as BPK to determine state finance loss. Until Constitutional Court Decision no.31/PUU-X/2012 clarify BPKP/FDSB authority in regards to laws and regulations. In this decision, Constitutional Court recognize BPKP/FDSB authority to conduct investigation audit in regards with Government Regulation No. 60 Year 2008 concerning Intern Government Control System. ${ }^{18}$ In

\footnotetext{
${ }^{14}$ Consideration Parts of President Decision No. 31 Year 1983.

${ }^{15}$ Article 1 President Decision No. 31 Year 1983.

${ }^{16}$ Article 3 (n) President Decision No. 31 Year 1983.

${ }^{17}$ BPKP, Brief History of BPKP, read in http//www.bpkp. go.id/konten/4/sejarah-Singkat-BPKP.bpkp, visited in 14 June 2015.

${ }^{18}$ Peraturan Pemerintah No. 60 Tahun 2008 tentang Sistem Pengendalian Intern Pemerintah
}

this regulation, it is clearly stated that BPKP/FDSB as a state non-department organs has authority to conduct investigation audit:

Article 47: First, Ministry/chief of department, governor, and regent/mayor are responsible of the effectively of Intern Control System inside its field; Second, To strengthen and provide the affectivity of Intern Control System, it can be done such: a. Intern supervision over the duties and function performance including accountability of state finance; b. SPIP ${ }^{19}$ coaching.

Article 49: First, Intern government supervision apparatus as referred in Article 48 (1) consist of: Second, BPKP/FDSB conduct intern supervision towards state finance accountability over the activities cover: a. Sectorial cross activity; b. General treasury activities based on Finance Ministry Decision; c. Any other activities as mandated by President.

Beside the Constitutional Court Decision which considered Government Regulation No. 60 Year 2008 and President Decision No. 103 Year 2001, BPKP/ FDSB Authority in conducting investigation audit is also recognized through President Regulation No. 192 Year 2014 concerning BPKP/FDSB. Article 3 (e) stated that: In performing its duty as referred to Article 2, BPKP/FDSB has functions: (e) supervision towards arrangement and execution programme and/ or activities which can resist the development, audit over price adjustment, claim audit, investigation audit towards some deviation cases which shows state/ region finance loss indication, state finance loss audit, give experts explanation, and efforts in eradicating and preventing corruption.

\section{Comparison between BPK or SAB and BPKP or FDSB Authorities}

If we see those audit organs authorities, both of them have same main authority which is audit. As stated in Guidance of BPKP/FDSB investigation, audit itself has several variety which clearly defined purpose of the audit itself. ${ }^{20}$ Audit is the process of collecting and evaluating any evidences about information that can be calculated about any effort conducted by competent and independent person for determining and reporting the suitability of the

\footnotetext{
${ }^{19}$ Sistem Pengendalian Intern Pemerintah.

${ }^{20}$ Pedoman Penugasan Bidang Investigasi, Peraturan Kepala BPKP No. PER-1314/K/D6/2012, Badan Pengawasan Keungan dan Pembangunan.
} 
information with any criteria which has been set. ${ }^{21}$ Audit with certain purposes is audit which conducted with certain purposes outside financial audit and performance audit, including state financial loss audit, investigation audit, claim audit, and price suitability audit. ${ }^{22}$ State finance loss audit is audit with certain purposes in order to determine the state finance loss that caused by such deviation case and used for litigation action. ${ }^{23}$ Investigation audit is the process of seeking, finding, and collecting any evidences systematically in order to reveal the existence of any action and the actor to be used in the next measure. ${ }^{24}$

But, if we analysis deeply, even though both organs has authority to audit the state finance, actually it does not mean that both of them have authority to determine state finance loss. It is because both of them have their own burden in what extend they can use the information of state finance loss. Constitutionally, only BPK which has authority to examine (in the scope of audit and/or investigate) the management and accountability of the state finance. BPK/SAB got the authority attributably from 1945 Constitution and according to Law No. 15 Year 2006 concerning BPK/SAB and any other Law such as Law about State Treasury and Examination of Management and Accountability of State Finance, only BPK/SAB has clear authority to determine state finance loss. It also supported by BPK/SAB authority to monitor the payment of state finance loss by the treasurer or any other state officer. In determining state finance loss, BPK/SAB can use the information from any other state organs or public accountant then BPK/ $\mathrm{SAB}$ will examine those information. But then, how

${ }^{21}$ Audit adalah proses pengumpulan dan pengevaluasian bukti tentang informasi yang dapat diukur mengenai suatu satuan usaha yang dilakukan seseorang yang kompeten dan independen untuk dapat menentukan dan melaporkan kesesuaian informasi dimaksud dengan kriteria-kriteria yang telah ditetapkan.

${ }^{22}$ Audit DenganTujuanTertentu adalah audit yang dilakukan dengan tujuan khusus di luar audit keuangan dan audit kinerja. Termasuk dalam audit tujuan tertentu ini adalah audit dalam rangka penghitungan kerugian keuangan negara, audit investigatif, audit klaim, dan audit penyesuaian harga.

${ }^{23}$ Audit Dalam Rangka Penghitungan Kerugian Keuangan Negara (PKKN) adalah audit dengan tujuan tertentu yang dimaksudkan untuk menyatakan pendapat mengenai nilai kerugian keuangan negara yang timbul dari suatu kasus penyimpangan dan digunakan untuk mendukung tindakan litigasi.

${ }^{24}$ Audit Investigatif adalah proses mencari, menemukan, dan mengumpulkan bukti secara sistematis yang bertujuan mengungkapkan terjadi atau tidaknya suatu perbuatan dan pelakunya guna dilakukan tindakan hukum selanjutnya. is about the BPKP/FDSB? If we take a look more at the basis work of BPKP/FDSB, BKPK had ever had authority to determine state finance loss based on President Decision No. 31 Year 1983, but this it has no longer been applicable since the enactment of President Decision No. 42 Year 2001. ${ }^{25}$ Beside this, BPKP/FDSB was established in order to maintain intern supervision across government organs. BPKP/ FDSB has only authority to conduct supervision and audit, but not determine state finance loss. According to Phillipus Hadjon, BPKP/FDSB can only audit in the scope of intern government supervisory. The BPKP/FDSB audit is conducted based on penyidik request and penyidik document. Therefore, there is no opinion that the result of BPKP/FDSB audit has the legally binding power because it is not based on the legality authority. ${ }^{26}$

$\mathrm{BPKP} / \mathrm{FDSB}$ as an intern government supervisory body, has Memorandum of Understanding (MoU) with Attorney and Police based on the Memorandum of Understanding No. KEP-109-A/JA/09/2007 (BPKP/FDSB number), No. B/2718/IX/2007 (police number), and No. KEP-1093/K/D6/2007 (Attorney number). This $\mathrm{MoU}$, in general, will help BPKP/ FDSB's partners to increase their affectivity in order to reach good governance. ${ }^{27} \mathrm{In}$ this MoU (article 4), stated that BPKP/FDSB can conduct investigation audit if Police and Attorney ask them and give the report to Police and Attorney. But actually, if it is seen in the scope Laws and Regulation, BPKP/FDSB report cannot be used by Police and Attorney to be the basis of investigation since BKPK has no authority to determine the state finance loss. BPKP/FDSB can only help the Attorney and Police to calculate the

${ }^{25}$ Dani Sudarsono statement, ex Chief Deputy of BPKP supervision of Central and Regional expenditure sector, in case of Mohammad Bahalwan application towards BPKP investigation sector in Adinistrative Court Jakarta, in regards to Life Time Extension (LTE) Gas Turbin (GT) 2.1. and 2.2 PLTGU Belawan case, read in http//m.liputan6.com/news/read/2119154/saksikorupsi-turbin-bpkp-tak-berwenang-hitung-kerugian-negara, visited in 10 June 2015.

${ }^{26}$ Phillipus M. Hadjon, Administrative law experts, in case of Mohammad Bahalwan application towards BPKP investigation sector in Adinistrative Court Jakarta, in regards to Life Time Extension (LTE) Gas Turbin (GT) 2.1. and 2.2 PLTGU Belawan case, read in http//m.liputan6.com/news/read/2119154/saksikorupsi-turbin-bpkp-tak-berwenang-hitung-kerugian-negara, visited in 10 June 2015.

${ }^{27}$ BPKP, Brief History of BPKP, read in http//www.bpkp. go.id/koneten/4/sejarah-Singkat-BPKP.bpkp, visited in 14 June 2015 . 
indication of state loss. But then, in the case when $\mathrm{BPKP} / \mathrm{FDSB}$ find indication, the report must be submitted to BPK/SAB, then BPK/SAB will examine the report whether it is fulfilled any requirements and elements of creating state finance loss.

If KPK, Attorney, and Police, as the law enforcers in regards to corruption eradication, use BPKP/ FDSB report as the basis of any evidence in state finance loss, actually it is contrary with Laws and Regulations. It is because BPKP/FDSB is only intern government supervisory organs which has authority to supervise the state finance across government organs and only conduct the audit, not determine whether the result of audit itself can be classified as state finance loss, since the Laws has regulated clearly that only BPK/SAB, which constitutionally got the authority as a supreme audit body and has authority to determine the state finance loss. But, this statement does not mean that the law enforcers cannot cooperate and coordinate with BPKP/FDSB, they can still cooperate and coordinate but the calculate report must be submitted first to BPK/SAB in order to get the certainty whether it really causes state finance loss.

Beside this, if we take a look at the judge consideration in Supreme Court Decision No. 946 K/ PDT/2011, in the case when there is disputes between state organs which based on constitution and state organs which based on Laws and Regulations, it means that the state organs which based on constitution will prevail. Substantially legalistic argumentative, from hermeneutic legal text interpretation in logic preposition approach, if there is authority disputes in regards with investigation/finance audit (include audit investigative) between attribution authority based on constitution legality (attribution authority from Article 23E and 23G 1945 Constitution to Law No. 15 Year 2004 and Law No. 15 Year 2006) with the non-constitutional attribution legality (attribution authority from Government Regulation No. 60 Year 2008 in scope of implementation of Intern Government Control System), the constitutional attribution will prevail. ${ }^{28}$ It might be concluded that $\mathrm{BPK} / \mathrm{SAB}$ as the state organs which constitutionally got the authority through attribution, is the state organs which has authority to determine state finance loss.

\footnotetext{
${ }^{28}$ Henrol Ferry Makawimbang, Kerugian Keungan Negara,
} Thala Media, Yogyakarta, 2014, p. 150.

\section{CLOSING}

State finance loss as one of elements of corruption must be clearly determined by the authorized state organs in order to gain the efficiency of AntiCorruption Law. If the state finance loss is not determined by authorized organs, it means that the state finance loss elements is not fully fulfilled and the efficiency of Anti-Corruption Law decreases. Even though KPK as one of authorized organs which has authority to cooperate with other organs in eradicating corruption, but in the case when KPK needs the evidence of state finance loss, KPK can only get the data of state finance loss from BPK/ $\mathrm{SAB}$, not from BPKP/FDSB. It because BPKP/ FDSB may only give the information about any such indication of state finance loss, not the data (officially determined) of the state loss. BPKP/ FDSB, indeed, had ever had authority to determine state finance loss under President Decision No. 31 Year 1983, but it has no longer been applicable and even though BPKP/FDSB in Constructional Court Decision No. 31/PUU-X/2012, is only given the authority to conduct investigation audit, but it is not including determining state loss. KPK under Article 6 Under 1945 Constitution and Law No. 15 Year 2006, only BPK which has authority to determine state finance loss, since the payment of the state finance law itself is under monitoring of BPK/ $\mathrm{SAB}$ also. In the case when KPK or any other Law enforcers, such Attorney and Police, get information about state finance loss whether from BPKP/FDSB or other informant, it must reported first to BPK/SAB in order to get classification whether the information can be classified as state finance loss. So if the law enforcers, such as KPK, Attorney, and Police do not really aware about how and until what extend BPKP/ FDSB has authority in regards to state finance loss, the elements of corruption as stated in Article 2 and 3 Anti-Corruption Law will not be fulfilled fully and clearly. It means that the efficiency of those articles will decrease since the law enforcers, in determining the fulfilment of the elements do not use the appropriate and authorized basis.

\section{BIBLIOGRAPHY}

\section{Laws and Regulation:}

Law No. 31 Year 1999 as amended by Law No. 20 Year 2001 concerning Coruption Eradction. 
Regulated in Law No. 30 Year 2002 concerning Corruption Eradiction Commission.

Law No. 17 Year 2003 concerning State Finance.

Law No. 1 Year 2004 concerning State Treasury.

Law No. 15 Year 2004 concerning Examination of Management and Acoountability of State Finance.

President Decision No. 31 Year 1983 concerning BPKP/FDSB.

President Decision No. 42 Year 2001 concerning position, Duties, Functions, Organization Arrangement, and Procedure of Government Organs Non Department.

President Decision No. 103 Year 2001 concerning position, Duties, Functions, Organization Arrangement, and Procedure of Government Organs Non Department.

President Regulation No. 192 Year 2014 concerning BPKP/FDSB.

Government Regulation No. 60 Year 2008 concerning Intern Government Control System.

BPK/SAB Regulation No. 3 Year 2007 concerning State Finance Loss Compensation Procedure.

\section{Books:}

Chazawi, Adami, 2014, Hukum Pidana Materiil dan Formil Korupsi di Indonesia, Malang: Bayu Media Publishing.

Hadjon, Philipus M., Fungsi Normatif Hukum Administrasi dalam Mewujudkan Pemerintahan yang Bersih, diucapkan pada peresmian penerimaan jabatan Guru Besar dalam Ilmu Hukum pada Fakultas Hukum Universitas
Airlangga pada hari Senin, tanggal 10 Oktober 1994.

Makawimbang, Henrol Ferry, 2014, Kerugian Keungan Negara, Yogyakarta: Penerbit Thala Media.

Pedoman Penugasan Bidang Investigasi, Peraturan Kepala BPKP No. PER-1314/K/D6/2012, Badan Pengawasan Keuangan dan Pembangunan.

Putra, Hidayat Pratama, "Tinjauan Hukum Audit Badan Pengawasan Keuangan dan Pembangunan Terhadap PT Indosat Tbk (Analisis Putusan PTUN Jakarta No. 231/G/2012/PTUN-JKT)", Skripsi (Thesis), Fakultas Hukum Univeritas Hasanuddin, Makassar, 2014.

Subagio, M., 1988, Hukum Keuangan Negara R.I., Jakarta: Rajawali Pers.

Tjandra, W. Riawan, 2006, Hukum Keuangan Negara, Jakarta: Grasindo.

\section{Court Decision:}

Supreme Court Decision No. 946 K/PDT/2011.

Jakarta Administrative Court Decision no.111/G/2014/ PTUN-JKT.

Constitutional Court Decision no.31/PUU-X/2012.

\section{Websites:}

BPKP, Brief History of BPKP, read in http//www. bpkp.go.id/koneten/4/sejarah-Singkat-BPKP. bpkp, visited in 14 June 2015

$\mathrm{http} / / \mathrm{m}$.liputan6.com/news/read/2119154/saksikorupsi-turbin-bpkp-tak-berwenang-hitungkerugian-negara, visited in 10 June 2015. 